\title{
First report of Thielaviopsis paradoxa causing stem rot in Dracaena marginata in Brazil
}

\author{
Álvaro Figueredo dos Santos ${ }^{1 *}$, Carlos Antonio Inácio ${ }^{2}$, Milton Vasconcelos Guedes ${ }^{3}$, Roberto Tomaz
}

\begin{abstract}
${ }^{1}$ Embrapa Florestas, Cx. Postal 319, 83411-000, Colombo, PR, Brasil; ${ }^{2}$ Universidade de Brasília, Brasília, DF, Brasil; ${ }^{3}$ Centro Diagnóstico Marcos Enrietti, Curitiba, PR. *Bolsista CNPq.

Author for correspondence: Álvaro Figueiredo dos Santos (alvaro@cnpf.embrapa.br)

Data de chegada: 10/08/2010. Aceito para publicação em: 22/06/2012.
\end{abstract}

Dracaena (Dracaena marginata), Dracaenaceae Salisb. (1866), also known as Ruscaceae or synonymous of Asparagaceae (APG II. Botanical Journal of the Linnean Society 141:399-436), is an evergreen ornamental shrub and has become increasingly popular in recent years as a palm-like specimen plant. This species is highly requested by interior designers and architects due to this feature. This plant is usually propagated by stem cuttings.

During the months of June and July 2006, several stem cuttings from dracaena were received at the Laboratory of Plant Pathology of "Embrapa Florestas" in Colombo, Paraná State (PR), Brazil, from a
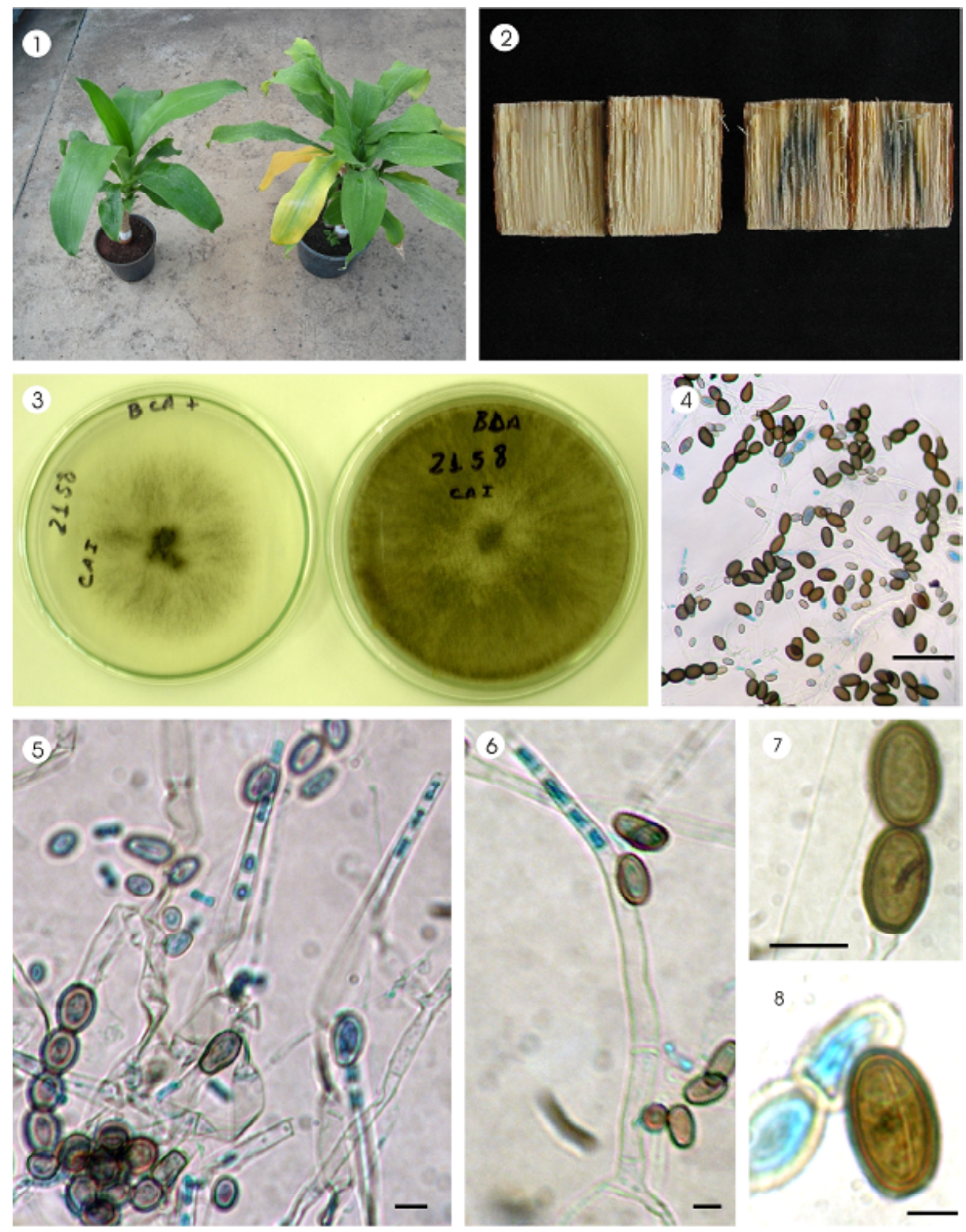

Figura 1. Symptoms on plants of "Dracena" Dracaena sp. (Ruscaceae) inoculated with Thielaviopsis paradoxa (Right) and not inoculated (left);

Figura 2. Details of longitudinal sections of inoculated stems (right) and not inoculated (left); Figuras 3 e 4. Conidia $(\mathrm{Bar}=50 \mu \mathrm{m})$. Colonies of T. paradoxa in PCA (Potato Carrot Agar) and PDA (Potato Dextrose Agar), respectively; Figuras 5 e 6. Conidiogenous cells $(\mathrm{Bar}=10 \mu \mathrm{m})$.

Figura 7. Brown conidia (chlamydospores) on chains $(\mathrm{Bar}=10 \mu \mathrm{m})$; Figura 8 . Longitudinal slit on conidia $($ Barra $=5 \mu \mathrm{m})$. 
nursery in the municipality of Morretes-PR. These stem cuttings had external and transversal sections on the darkening tissue (Figure 2), affecting their quality. This study aimed to identify the causal agent of this disease.

Samples of the stem cuttings showing different stages of symptoms were collected and isolated on plates containing Potato Dextrose Agar (PDA), a medium supplemented with ampicillin and chloramphenicol. The plates were incubated at $25^{\circ} \mathrm{C}$, in the dark, for 7 days. Once isolated, the fungus was identified as Thielaviopsis sp. based on its morphological characteristics (Ellis MB (1971) Dematiaceous hyphomycetes. CMI, Kew, Surrey; Ellis MB (1971) More dematiaceous hyphomycetes. CMI, Kew, Surrey; Farr DF, Rossman AY., from http://nt.ars-grin.gov/fungaldatabases); and Paulin-Mahady AE, HarringtonTC (2002)-Mycologia 94: 62-72.). One isolate was deposited in "Embrapa Florestas" (Collection number TP1) and UNB (2158).

A pathogenicity test was performed, consisting in the inoculation of stem cuttings and plants of dracaena by placing small PDA dishes ( $5 \mathrm{~mm}$ in diameter) containing fungal mycelium into damaged areas in the stem cuttings and plants. The fungus was pathogenic to both stem cuttings and plants, causing internal darkening of the stem and yellowing of the leaves at one month after inoculation (Figures 1 and 2).

The fungus was re-isolated in PDA and the colonies were maintained in the culture medium for morphological characterization, which indicated it was Thielaviopsis paradoxa (De Seynes) Höhn (Upadhyay HP (1981) A monograph of Ceratocyslis and Ceratocysliopsis. University of Georgia Press, Athens), showing colonies that were grayish to grayish-green occupying all plates after 10 days of incubation in PDA (12h light/dark; $\pm 22^{\circ} \mathrm{C}$ ) (Figure $3)$, dark on the lower side, rugose; conidiophores $85-180 \times 4-10$ $\mu \mathrm{m}$, straight, sometimes sinuous at the base, hyaline to light-brown, septated at the base, smooth; conidiogenous cells 57-80 × 7-10 $\mu \mathrm{m}$, lageniform, sometimes cylindrical, hyaline, 3-4 $\mu \mathrm{m}$ diameter at the apex (Figures 5 and 6). Conidia were sometimes cylindrical 4-14 $\times 2-3 \mu \mathrm{m}$, truncate at the ends, phialidic, smooth, hyaline, becoming light-brown or sometimes varying in shape, cylindricaloval or slightly ellipsoidal, 4-21 × 3-6 $\mu \mathrm{m}$, with longitudinal slit, smooth or in chains (Figures 3, 7 and 8). The teleomorph Ceratocystis paradoxa (Dade) C. Moreau, which now includes the name $T$. paradoxa (Kirk (2009), Index fungorum. http:// www.speciesfungorum.org/), was not observed. This is the first report of an anamorph of Ceratocystis paradoxa causing disease in dracaena in Brazil.

\section{ACKNOWLEDGEMENT}

The authors would like to thank José César Castro (UnB) for his excellent technical assistance. 